\title{
Genetic relatedness among Japanese, American and European isolates of viral hemorrhagic septicemia virus (VHSV) based on partial $\mathbf{G}$ and $P$ genes
}

\author{
T. Nishizawa ${ }^{1, *}$, H. Iida ${ }^{1}$, R. Takano ${ }^{1}$, T. Isshiki ${ }^{2}$, K. Nakajima ${ }^{3}$, K. Muroga ${ }^{1}$ \\ ${ }^{1}$ Faculty of Applied Biological Science, Hiroshima University, Higashi-Hiroshima 739-8528, Japan \\ ${ }^{2}$ Kagawa Prefectural Fisheries Experiment Station, Takamatsu 761-0111, Japan \\ ${ }^{3}$ National Research Institute of Aquaculture, Nansei, Mie 516-0193, Japan
}

\begin{abstract}
Molecular virological analyses of 8 Japanese VHSV (viral hemorrhagic septicemia virus) isolates from wild and farmed Japanese flounder Paralichthys olivaceus were performed to investigate their genetic relatedness to American and European isolates of VHSV. Phylogenetic analyses based on the partial nucleotide sequences of $G$ and $P$ genes revealed that there are 2 genogroups of VHSV in Japan. The first one represented by the Obama25 isolate is closely related to the American isolates (Genogroup I) while the other, the KRRV9601 isolate, is closely related to the traditional European isolates (Genogroup III). The 2 types of Japanese VHSV showed differences in the relative mobility of the $\mathrm{G}$ protein and intensity of the antibody reaction on the $\mathrm{P}$ and $\mathrm{M}$ proteins. The Obama25 type of VHSV is widely distributed as a native virus in the coastal areas of western Japan and has been responsible for the occurrence of VHSV infection in farmed Japanese flounder while the KRRV9601 isolate is considered to have been introduced from a foreign country.
\end{abstract}

KEY WORDS: Viral hemorrhagic septicemia virus · Paralichthys olivaceus ' VHSV - phylogenetic analysis · G gene $\mathrm{P}$ gene $\cdot$ M1 gene

Resale or republication not permitted without written consent of the publisher

Viral hemorrhagic septicemia (VHS) is the most serious viral disease of farmed rainbow trout Oncorhynchus mykiss in continental European countries. The causative agent of VHS has a widespread distribution in a variety of freshwater and marine fishes (Mortensen et al. 1999, Smail 1999). The first isolation of marine VHSV was from Atlantic cod Gadus morhua in 1979 (Jensen et al. 1979, Vestergård-Jørgensen \& Olesen 1987), and subsequently outbreaks were reported in sea-farmed rainbow trout in France (Castric

*E-mail: jjnishi@hiroshima-u.ac.jp
\& de Kinkelin 1980), and turbot Scophthalmus maximus in Germany and Scotland (Schlotfeldt et al. 1991, Ross et al. 1994). In addition, VHSV has been isolated from several wild marine fishes, such as cod and herring Clupea harengus (Mortensen et al. 1999). The first American VHSV was isolated from returning chinook salmon $O$. tshawytscha and coho salmon O. kisutch in western North America in 1988 (Brunson et al. 1989, Winton et al. 1989). The same type of VHSV strains were isolated from Pacific cod G. macrocephalus, Pacific herring $C$. harengus pallasi and other marine fishes (Meyers et al. 1992, 1994, 1999). On the other hand, VHSV has never been isolated from fishes in East Asian countries although distribution of other fish pathogenic novirhabdoviruses such as infectious hematopoietic necrosis virus (IHNV) and hirame rhabdovirus (HIRRV) were reported (Kimura \& Yoshimizu 1991, Nishizawa et al. 1991). In 1999, VHSV was first isolated in Japan from wild Japanese flounder Paralichthys olivaceus during a survey on the distribution of fish viruses in wild marine fishes (Takano et al. 2000, 2001). Recently, rhabdoviral infections occurred in farmed Japanese flounder in the Seto Inland Sea of Japan and the causative agent was identified as VHSV (Isshiki et al. 2001).

VHSV, a member of the genus Novirhabdovirus of the family Rhabdoviridae, has a single molecule of linear, negative-sense ss-RNA (approximately $11.1 \mathrm{~kb}$ ) with 6 genes in the order 3'-N-P-M-G-NV-L-5' (Walker et al. 2000). The phylogenetic analysis based on the nucleotide sequences of the partial G gene of VHSV isolates from marine and freshwater fishes revealed 3 genogroups, I, II and III (Benmansour et al. 1997, Stone et al. 1997). The American isolates of VHSV from marine fishes are assigned to the Genogroup I while 
the Scotland isolates from marine fishes are in the Genogroup II. All of the other VHSV isolates, the traditional European isolates from marine and freshwater fishes, are clustered in the Genogroup III (Stone et al. 1997). However, the genetic relatedness of Japanese VHSV isolates to the American and European isolates has not been investigated. In the present study, analyses of the structural proteins and nucleotide sequences of Japanese VHSV isolates were made to investigate their genetic relatedness with the known American and European isolates of VHSV.

Materials and methods. Eight VHSV isolates (Obama25, KRRV9601, KRRV9822, KRRV0012, Fukuya00, Hakata00, JF00Ehi1 and JF00Oit1) were used in this study. The Obama25 and Hakata00 isolates were from wild Japanese flounder taken from Wakasa Bay in the Japan Sea in 1999 and from a coastal area of Hakata Island in the Seto Inland Sea in 2000, respectively. The other isolates (KRRV9601, KRRV9822 and KRRV0012) were from farmed Japanese flounder collected from the Kagawa Prefecture in 1996, 1998 and 2000, respectively, while Fukuya00, JF00Ehi1 and JF00Oit1 were isolated from Japanese flounder collected from the Hiroshima, Ehime and Oita Prefectures, respectively, in 2000 (Fig. 1).

VHSV isolates were grown in the fathead minow (FHM) cell line which was maintained in Eagle's minimal essential medium (MEM) supplemented with $10 \%$ (V/V) fetal bovine serum at $20^{\circ} \mathrm{C}$, and then concentrated by centrifugation $\left(100000 \times g, 1 \mathrm{~h}, 4^{\circ} \mathrm{C}\right)$. Viral structural proteins were analyzed by SDS-PAGE using $10 \%$ polyacrylamide gel under the reducing condi-
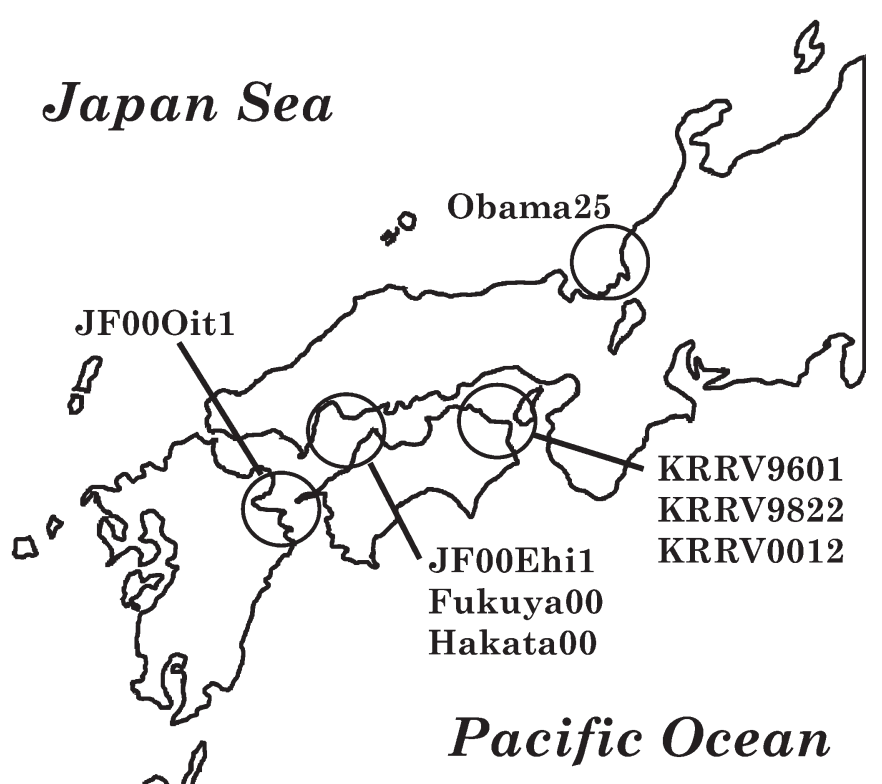

Fig. 1. Geographical locations of the fishing sites of Japanese flounder for each isolate of VHSV tions of Laemmli (1970) and stained with silver nitrate. After SDS-PAGE, the separated viral proteins were electroblotted onto a nitrocellulose membrane following the procedure of Towbin et al. (1979) and immunostained with 3 different antisera against VHSV (A/S DK-F59 [Olesen \& Lorenzen 1999], A/S Obama25 and A/S KRRV9601), and then visualized with an alkaline phosphatase conjugate substrate kit (Bio-Rad) according to the manufacturer's instructions. A/S Obama25 and A/S KRRV9601 were prepared in our laboratory. Purification of each virus isolate was performed from the supernatant of infected FHM cells following the procedures described by Nishizawa et al. (1991). The purified virus was emulsified with Freund's incomplete adjuvant (Nacalai Tesque) and injected intramuscularly into a rabbit. After 2 booster intravenous injections with the purified virus, each antiserum was obtained.

For nucleotide sequence analysis, RNA was extracted from virus culture fluid using an RNA extraction kit (ISOGEN-LS, Nippon Gene) according to the manufacturer's instructions, and was submitted to RT-PCR amplification with 2 different PCR primer sets. The first primer set, VM1sense (5'-CACATGRC-TGATATTGAGATGAG-3') and VM1anti (5'-CTTGTCCAMSTCCGCCTTG-3'), was used for amplification of a 663 base region of the VHSV P gene (nt-3-659) (Takano et al. 2000). Another primer set, VGsense (5'-CCAGCTCAACTCAGGTGTCC-3') and VGanti (5'-GTCACYGTGCATGCCATTGT-3'), targeting a 587 base region of the VHSV G gene (nt 175-761), was designed based on nucleotide sequences of VHSV 07-71 and Makah strains (accession numbers U02624 and U02630). In the RT-PCR reaction, annealing temperatures of each primer set for $\mathrm{G}$ and $\mathrm{P}$ genes were 52 and $60^{\circ} \mathrm{C}$, respectively. After purification by $1.5 \%$ agarose gel electrophoresis, the PCR products were submitted for determination of the nucleotide sequence with an $\mathrm{ABI}$ PRISM $^{\circledR}$ cycle sequencing kit (ABI) according to the manufacture's instructions. Nucleotide sequences were assembled and analyzed with DNASIS (Hitachi Software Engineering), and multiple alignments of the determined sequences were constructed by the Clustal W program (Thompson et al. 1994) to search for an optimal tree with neighbor joining criteria. The final phylogenetic tree was drawn with the DendroMaker program (Imanishi 2001).

Results and discussion. Comparisons of viral structural proteins among 8 isolates of VHSV were made by SDS-PAGE and western blot analyses with A/Ss DKF59, Obama25 and KRRV9601 (Fig. 2). Four viral structural proteins, G, N, P and M, were strongly stained with all antisera and their electrophoresis patterns were quite similar to each other. However, differences in the relative mobility of the $\mathrm{G}$ protein and the inten- 

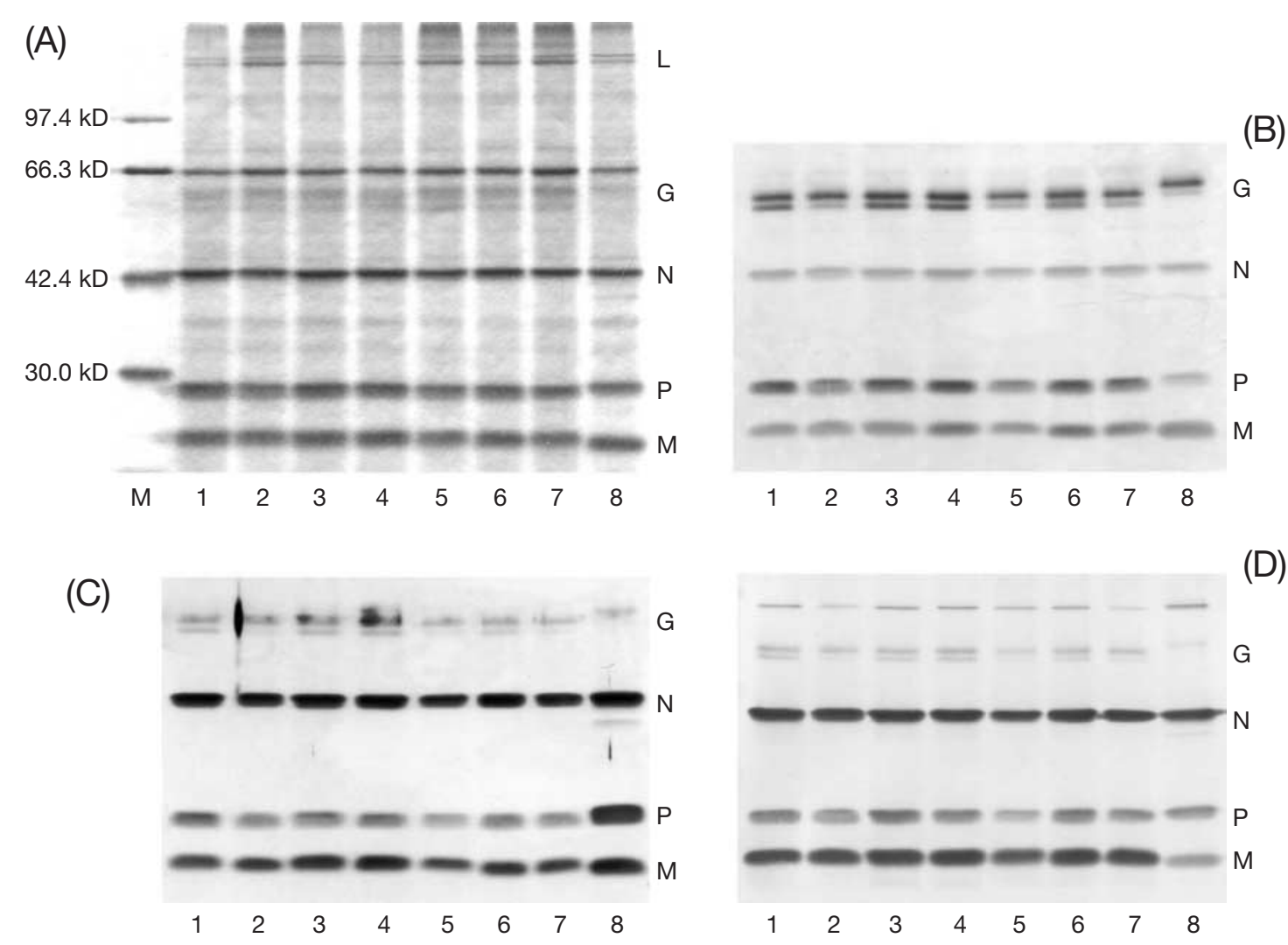

\section{(B)} .

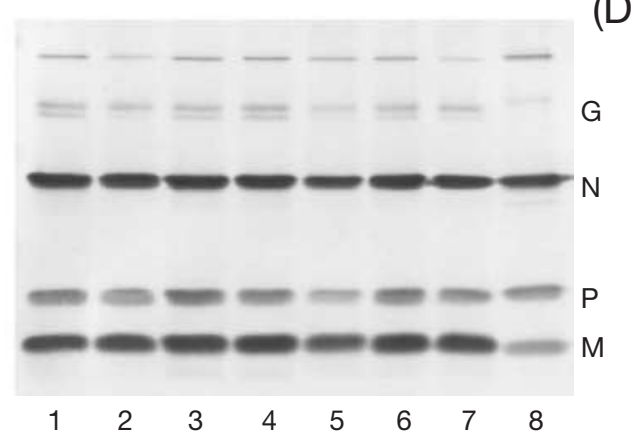

Fig. 2. SDS-PAGE and western blot analyses of viral structural proteins (L, G, N, P, M) of Japanese VHSV isolates. (A) SDS-PAGE $(10 \%$ gel) stained with silver nitrate. Western blot (B) with antiserum VHSV (DK-F59); (C) with A/S KRRV9601, (D) with A/S Obama25. Lanes 1-8 were Obama25, JF00Oit1, Fukuya00, KRRV9822, JF00Ehi1, Hakata00, KRRV0012 and KRRV9601, respectively. $\mathrm{M}$ on $\mathrm{X}$-axis: molecular marker

sity of the antibody reaction on the $\mathrm{P}$ and $\mathrm{M}$ proteins were observed between KRRV9601 (Fig. 2, lane 8) and the other 7 isolates. In particular, the KRRV9601 G protein was slightly bigger than the rest of the isolates. After immunostaining with A/S DK-F59, the reaction intensity of the P protein of KRRV9601 was slightly weaker than those of the other 7 isolates (Fig. 2B), while the reaction intensity of the $M$ protein of KRRV9601 against A/S Obama25 was slightly weaker than those of the others (Fig. 2D). On the other hand, the reaction intensity of the KRRV9601 P protein was stronger than the others using A/S KRRV9601 (Fig. 2C). These results indicate that the structural proteins of KRRV9601 are distinguishable from those of the other Japanese VHSV isolates. However, it was not possible to distinguish KRRV9601 from the other isolates using a neutralization test (data not shown). Also, no difference in the structural protein pattern was observed among Japanese isolates from wild and farmed Japanese flounders except in the case of the KRRV9601 isolate.

From all 8 Japanese isolates, PCR products with approximately 590 and 660 bp were obtained by RT-PCR with the primer sets for $\mathrm{G}$ and $\mathrm{P}$ genes, respectively, (data not shown). Sequence data of the G and P genes of Obama25 and KRRV9601 have been registered with the DNA data bank of Japan (accession numbers: AB060725-AB060728). The determined nucleotide sequences of the partial $G$ gene (nt 361-720) and $P$ gene (nt 21-642) of the 8 Japanese VHSV isolates were compared with those of Makah (accession numbers: U28747 and U02630) and 07-71 (accession number: AJ233396), which are the American and European VHSV type strains, respectively (Table 1). The nucleotide sequences of both the $\mathrm{G}$ and $\mathrm{P}$ genes of the 7 Japanese isolates (Obama25, JF00Oit1, Fukuya00, KRRV9822, JF00Ehi1, Hakata00 and KRRV0012) and the Makah isolate were more than $98 \%$ homogeneous, but the sequences of the $\mathrm{G}$ and $\mathrm{P}$ genes in these 7 isolates were less than $86 \%$ homogeneous with the KRRV9601 and 07-71 isolates. On the other hand, the $\mathrm{G}$ and P genes of KRRV9601 shared more than $97 \%$ similarity with that of 07-71.

A phylogenetic tree based on the nucleotide sequences of the partial G gene (nt 361-720) of 51 VHSV isolates is shown in Fig. 3. The nucleotide sequence data 


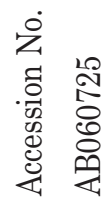

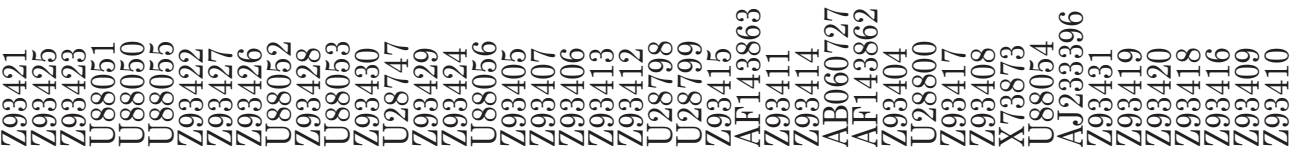
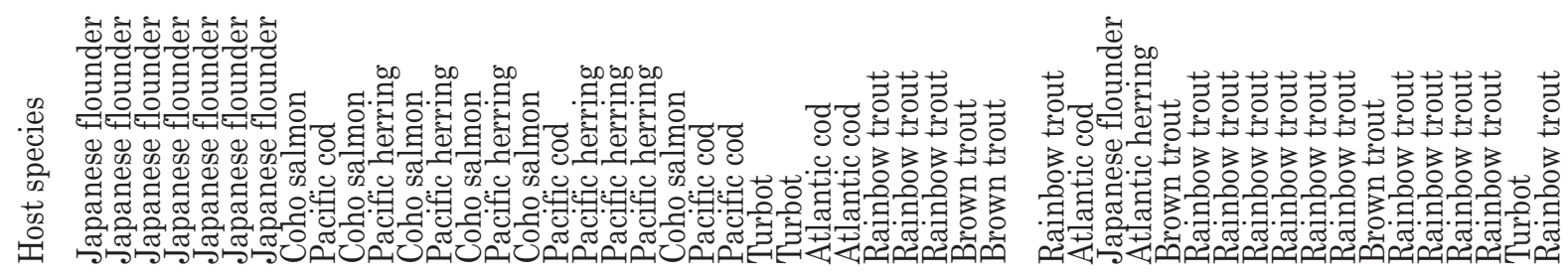

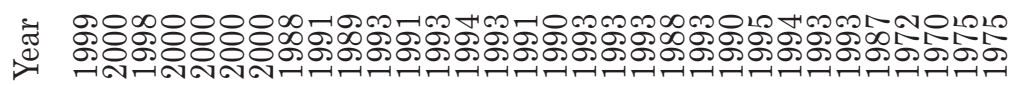

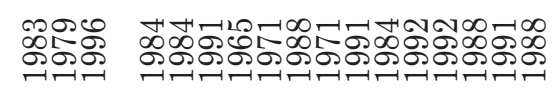

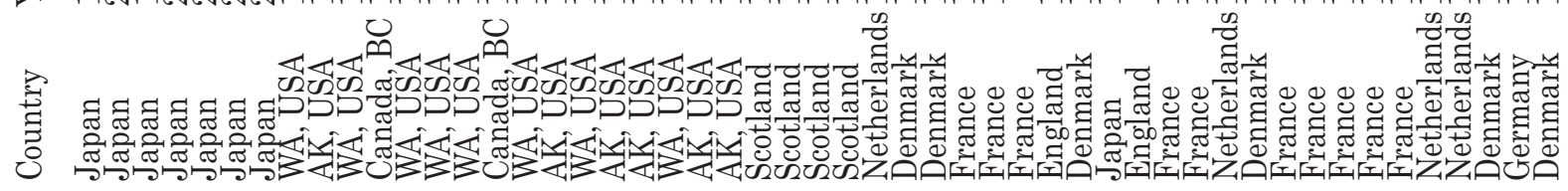

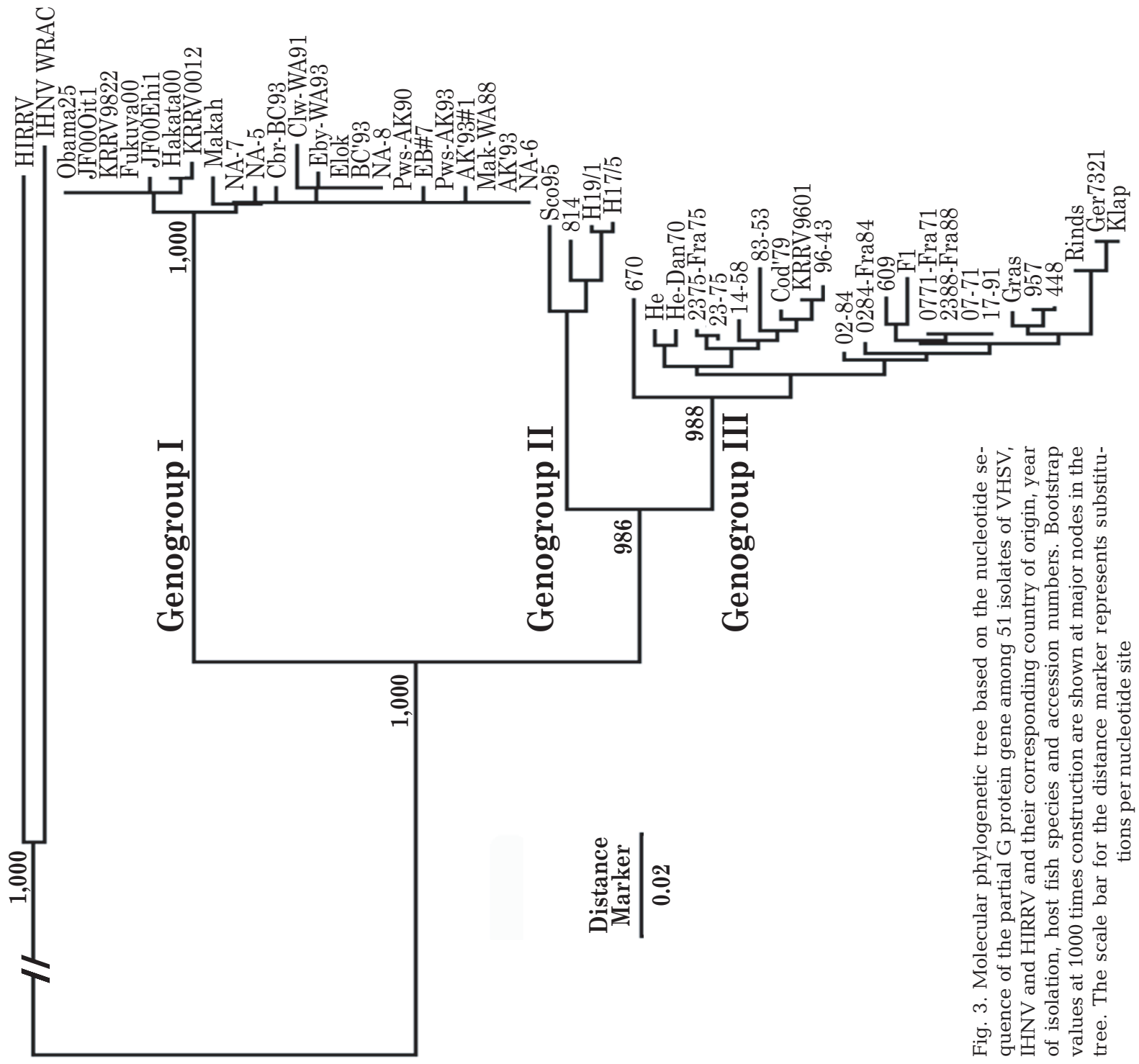


Table 1. Nucleotide sequence identities (\%) of the partial G gene (nt 361-720) and P gene (nt 21-624) comparing Japanese VHSV isolates with known VHSV isolates, Makah and 07-71

\begin{tabular}{|c|c|c|c|c|c|c|c|c|}
\hline \multirow[t]{2}{*}{ Isolates } & \multicolumn{2}{|c|}{ Makah } & \multicolumn{2}{|c|}{ Obama25 } & \multicolumn{2}{|c|}{ KRRV9601 } & \multicolumn{2}{|c|}{$07-71$} \\
\hline & G gene & P gene & G gene & P gene & G gene & P gene & G gene & P gene \\
\hline Makah & 100 & 100 & - & - & 83.9 & 84.6 & 84.4 & 84.4 \\
\hline Obama25 & 99.2 & 98.9 & 100 & 100 & 83.9 & 85.4 & 84.4 & 85.2 \\
\hline JF00Oit1 & 99.2 & 98.7 & 100 & 99.8 & 83.9 & 85.2 & 84.4 & 85.0 \\
\hline Fukuya00 & 99.2 & 98.6 & 100 & 99.7 & 83.9 & 85.4 & 84.4 & 85.2 \\
\hline KRRV9822 & 99.2 & 98.7 & 100 & 99.8 & 83.9 & 85.2 & 84.4 & 85.0 \\
\hline JF00Ehi1 & 98.9 & 98.7 & 99.7 & 99.8 & 83.6 & 85.5 & 84.2 & 85.4 \\
\hline Hakata00 & 98.9 & 98.4 & 99.7 & 99.5 & 83.6 & 85.5 & 84.2 & 85.4 \\
\hline KRRV0012 & 98.6 & 98.6 & 99.4 & 99.7 & 83.3 & 85.7 & 83.9 & 85.5 \\
\hline KRRV9601 & 83.9 & 84.6 & 83.9 & 85.4 & 100 & 100 & - & - \\
\hline $07-71$ & 84.4 & 84.4 & 84.4 & 85.2 & 98.3 & 97.4 & 100 & 100 \\
\hline
\end{tabular}

late 1970s. Those of Genogroups I and II were not found until the late 1980s because they were avirulent to salmonid fishes (Castric \& de Kinkelin 1980, Dixon et al. 1997, Kocan et al. 1997). Stone et al. (1997) suggested that all marine fish species are potential VHSV carriers since VHSV has often been isolated from several Atlantic and Pacific marine fishes. This evidence gives weight to the idea that VHSH may well have a marine origin (Smail 1999). Therefore, it is not surprising that VHSV was isolated from marine fish from the Japanese coast even though no VHSV has been detected from salmonid fishes in Japan.

of the G gene of IHNV (accession number: L40883) and HIRRV (accession number: U24073) were used as the outgroup to determine the root of the present VHSV isolates. The present phylogenetic tree revealed that VHSV isolates diverged into 3 major clusters as described previously (Benmansour et al. 1997, Stone et al. 1997). As defined by Stone et al. (1997), Genogroup I includes American isolates; Genogroup II includes Scotland isolates; and Genogroup III includes traditional European isolates. Seven of the Japanese isolates including Obama25 formed 1 minor cluster in Genogroup I while KRRV9601 is located in Genogroup III, which is closely related to the isolates Cod '79 and 96-43 which were isolated from Atlantic cod and Atlantic herring, respectively (Fig. 3). A similar result was observed in a phylogenetic tree constructed based on the nucleotide sequence of the P gene (data not shown).

The obtained results revealed that at least 2 different genotypes of VHSV exist in the western part of Japanese coastal areas; the first type is represented by the Obama25 isolate belonging to Genogroup I and the other type is the KRRV9601 isolate belonging to Genogroup III (Fig. 3). In subsequent surveys (Takano et al. 2001, Nakajima et al. unpubl. data), an additional 30 isolates of VHSV were isolated from randomly collected wild and farmed Japanese flounder in different coastal areas of Japan, which were all confirmed to be the American type VHSV belonging to Genogroup I by RT-PCR with the primers designed by EinerJensen et al. (1995). Thus, the present study has revealed that the VHSV strain of the Obama25 type is widely distributed in coastal areas of western Japan causing VHSV infection in farmed Japanese flounder.

Although VHS has been described since the 1930s, VHSV of Genogroup III was first isolated from a freshwater fish in the 1960s and from a marine fish in the
VHSV is considered to have diverged into 3 different genogroups a long time ago, before fish farming was extensively practiced (Benmansour et al. 1997). Benmansour et al. (1997) also reported that no molecular clock could be deduced from their phylogenetic tree based on the nucleotide sequences of the VHSV G gene. The same tendency was also obtained in our results, i.e. a weak relationship was observed between the date and position of viral isolation in each major cluster of the present phylogenetic tree. The Obama25 type of Japanese isolate formed 1 minor cluster in Genogroup I, but no American isolate is in this cluster (Fig. 3). This indicates that the Obama type may not have been introduced from America but could be a native VHSV in Japanese coastal areas.

On the other hand, the KRRV9601 type of VHSV was isolated only once from farmed Japanese flounder in 1996 and has not been isolated since. KRRV9822 and KRRV0012 were isolated in 1998 and 2000 in the same coastal area where KRRV9601 was isolated. However, as mentioned above, these 2 isolates are virologically identical to Obama25, which belongs to Genogroup I while KRRV9601 belongs to Genogroup III. Moreover, the present phylogenetic tree reveals that KRRV9601 is closely related to the Cod'79 and 96-43 isolates from Atlantic cod and Atlantic herring, respectively (Fig. 3). Therefore, KRRV9601 was thought to have been accidentally introduced from a foreign country to Japan, although its transmission path is not clear.

Acknowledgements. We wish to thank Dr. N. J. Olesen for providing the antiserum against VHSV (DK-F59) used in this study. This study was partly supported by a grant from the Ministry of Education, Science, Sport and Culture of Japan (Grant-in-aid for Scientific Research [C], grant number: 12660172). 


\section{LITERATURE CITED}

Benmansour A, Basurco B, Monnier AF, Vende P, Winton JR, de Kinkelin P (1997) Sequence variation of the glycoprotein gene identifies three distinct lineages within field isolates of viral haemorrhagic septicaemia virus, a fish rhabdovirus. J Gen Virol 78:2837-2846

Brunson R, True K, Yancey J (1989) VHS virus isolated at Makah National Fish Hatchery. Am Fish Soc Fish Health Sec Newsl 17:3-4

Castric J, de Kinkelin P (1980) Occurrence of viral haemorrhagic septicaemia in rainbow trout Salmo gairdneri Richardson reared in sea-water. J Fish Dis 3:21-27

Dixon PF, Feist S, Kehoe E, Parry L, Stone DM, Way K (1997) Isolation of viral haemorrhagic septicaemia virus from Atlantic herring Clupea harengus from the English Channel. Dis Aquat Org 30:81-89

Einer-Jensen $\mathrm{K}$, Olessen NJ, Lorenzen N, Jørgensen PEV (1995) Use of the polymerase chain reaction (PCR) to differentiate serologically similar viral haemorrhagic septicaemia (VHS) virus isolates from Europe and America. Vet Res 26:464-469

Imanishi T (2001) DendroMaker Ver.4. Center for Information, Biology National Institute of Genetics, Mishima

Isshiki T, Nishizawa T, Kobayashi T, Nagano T, Miyazaki T (2001) An outbreak of VHSV (viral hemorrhagic septicemia virus) infection in farmed Japanese flounder Paralichthys olivaceus in Japan. Dis Aquat Org 47(2):87-99

Jensen NJ, Bloch B, Larsen JL (1979) The ulcus-syndrome in cod (Gadus morhua) III. A preliminary virological report. Nord Vet Med 31:436-442

Kimura T, Yoshimizu M (1991) Viral diseases of fish in Japan. Annu Rev Fish Dis 1:67-82

Kocan R, Bradley M, Elder N, Meyers T, Batts W, Winton J (1997) North American strain of viral hemorrhagic septicemia virus is highly pathogenic for laboratory-reared Pacific herring. J Aquat Anim Health 9:278-290

Laemmli UK (1970) Cleavage of structural proteins during the assembly of the head of bacteriophage T4. Nature 227: $680-685$

Meyers TR, Sullivan J, Emmenegger E, Follett J, Short S, Batts WN, Winton JR (1992) Identification of viral hemorrhagic septicemia virus isolated from Pacific cod Gadus macrocephalus in Prince William Sound, Alaska, USA. Dis Aquat Org 12:167-175

Meyers TR, Short S, Lipson K, Batts WN, Winton JR, Wilcock J, Brown E (1994) Association of viral hemorrhagic septicemia virus with epizootic hemorrhages of the skin in Pacific herring Clupea harengus pallasi from Prince William Sound and Kodiak Island, Alaska, USA. Dis Aquat Org 19:27-37

Meyers TR, Short S, Lipson K (1999) Isolation of the North American strain of viral hemorrhagic septicemia virus (VHSV) associated with epizootic mortality in two new host species of Alaskan marine fish. Dis Aquat Org 38: 81-86

Mortensen HF, Heuer OE, Lorenzen N, Otte L, Olesen NJ

Editorial responsibility: Jo-Ann Leong,

Corvallis, Oregon, USA
(1999) Isolation of viral haemorrhagic septicaemia virus (VHSV) from wild marine fish species in the Baltic Sea, Kattegat, Skagerrak and the North Sea. Vir Res 63:95-106 Nishizawa T, Yoshimizu M, Winton J, Ahne W, Kimura T (1991) Characterization of structural proteins of hirame rhabdovirus, HRV. Dis Aquat Org 10:167-172

Olesen NJ, Lorenzen N (1999) Production of neutralizing antisera against viral hemorrhagic septicemia (VHS) virus by intravenous injections of rabbits. J Aquat Anim Health 11: $10-16$

Ross K, McCarthy U, Huntly PJ, Wood BP, Stuart D, Rough EI, Smail DA, Bruno DW (1994) An outbreak of viral haemorrhagic septicaemia (VHS) in turbot (Scophthalmus maximus) in Scotland. Bull Eur Assoc Fish Pathol 14:213-214

Schlotfeldt HJ, Ahne W, Vestergård-Jørgensen PE, Glende W (1991) Occurrence of viral haemorrhagic septicaemia in turbot (Scophthalmus maximus) - a natural outbreak. Bull Eur Assoc Fish Pathol 11:105-107

Smail DA (1999) Viral haemorrhagic septicaemia. In: Woo PTK, Bruno DW (eds) Fish diseases and disorders, Vol 3. Viral, bacterial and fungal infections. CABI Publishing, New York, p 123-147

Stone DM, Way K, Dixon PF (1997) Nucleotide sequence of the glycoprotein gene of viral haemorrhagic septicaemia (VHS) viruses from different geographical areas: a link between VHS in farmed fish species and viruses isolated from North Sea cod (Gadus morhua L.). J Gen Virol 78: $1319-1326$

Takano R, Nishizawa T, Arimoto M, Muroga K (2000) Isolation of viral haemorrhagic septicaemia virus (VHSV) from wild Japanes flounder Paralichthys olivaceus. Bull Eur Assoc Fish Pathol 20:186-192

Takano R, Mori K, Nishizawa T, Arimoto M, Muroga K (2001) Isolation of viruses from wild Japanese flounder Paralichthys olivaceus. Fish Pathol 36:153-160

Thompson JD, Higgins DG, Gibson TJ (1994) Clustal W: improving the sensitivity of progressive multiple sequence alignment through sequence weighing, positions-specific gap penalties and weight matrix choice. Nucleic Acids Res 22:4673-4680

Towbin H, Staehelin T, Gordon J (1979) Electrophoretic transfer of proteins from polyacrylamide gels to nitrocellulose sheets: procedure and some applications. Proc Natl Acad Sci USA 76:4350-4354

Vestergård-Jørgensen PE, Olesen NJ (1987) Cod ulcus syndrome rhabdovirus is indistinguishable from the Egtved (VHS) virus. Bull Eur Assoc Fish Pathol 7:73-74

Walker PJ, Benmansour A, Calisher $\mathrm{CH}$, Dietzgen R and 7 others (2000) Family Rhabdoviridae. In: van Regenmortel MHV, Fauquet CM, Bishop DHL, Carstens EB and 7 others (eds) Virus taxonomy. Seventh report of the international committee for taxonomy of viruses. Academic Press, San Diego, p 563-583

Winton JR, Batts WN, Nishizawa T, Stehr CM (1989) Characterization of the first North American isolates of viral hemorrhagic septicemia virus. Am Fish Soc Fish Health Sect Newsl 17:2-3

Submitted: June 15, 2001; Accepted: November 9, 2001

Proofs received from author(s): February 20, 2002 